\title{
Students' Attitudes at Amman Arab University towards the Pre-Marital Medical Examination and Its Role in Reducing Disability from Their Point of View
}

\author{
Ahmad Khazaleh ${ }^{1}$, Tayel Abdel Hafez Hwaidi ${ }^{1}$, Mo'en Salman Alnasraween ${ }^{1}$ \& Heyam Al-Taj ${ }^{1}$ \\ ${ }^{1}$ Amman Arab University, Jordan \\ Correspondence: Ahmad Khazaleh, Amman Arab University, Jordan.
}

Received: May 29, 2018

Accepted: July 21, 2018

Online Published: December 28, 2018

doi:10.5539/ies.v12n1p80

URL: https://doi.org/10.5539/ies.v12n1p80

\begin{abstract}
The purpose of this study is to identify the attitudes of the students of Amman Arab University toward pre-marital medical examination; it also aims to identify the role of premarital examination in reducing the appearance of disabilities. This study used the descriptive method; the sample of the study consisted of 200 undergraduate and master's students at Amman Arab University from the different faculties and academic years for the year (2017-2018). The researchers used a questionnaire; it consisted in its final form of 24 items. The results of the study showed that the mean of the total score of the role of the medical examination from the point of view of young people came to a high level; results also showed that there are no differences due to the gender of the student or the type of college.
\end{abstract}

Keywords: pre-marital medical examination, disability, students of Amman Arab University

\section{Introduction}

The knowledge of individuals about developments in the medical field is necessary to obtain support and acceptance of them, it is not acceptable to develop methods of medical intervention that do not receive the attention or face rejection of people, and from this perspective, knowledge of people's attitudes towards medical issues and its acceptability is important to know the attitudes of people towards pre-marital medical examinations, including genetic testing, as the trends vary towards genetic medical examinations by different types of tests and different characteristics and traits of individuals, trends are only positions formed by experience and knowledge and the nature of the individual in terms of Social and psychological characteristics. In addition, the issue of genetic medical examinations and related issues can affect people's attitudes towards conducting such tests (Obeidi, 2005).

Psychosocial factors are known to affect the health behavior of the individual, either to improve his health status, or to reverse his health. The individual's habits and beliefs affect the health level. Many people accept the change in his or her life if it is related to his or her religious faith. The religious faith aspect has a strong impact on the health of individuals in the society. It is easy to convince people that it is important to strive for all that harms health for them and for future generations. The process of change in the health behavior of individuals needs to develop well-considered health plans that take into account the conditions of the society and its culture and beliefs. in addition to the need to develop policies and laws that control the desired behavior to be changed, and therefore these health plans are under continuous assessment of how effective it is in bringing about change in a particular health behavior (Al Bather, 2005).

The process of conducting premarital medical examination is a thorny issue of varying dimensions. It may be a reason for marriage to succeed and strengthen it, or it can play an effective role in making a difficult decision to separate and leave. Whatever the outcome, the fact is that premarital medical examination is the first step in building a family that represents the foundation of society. The family is the first cell to make up the body of the society, so that it is good for this body and its corruption is affected by stasis and disintegration (Al Jaber, 2006).

Therefore, Islam is concerned with the affairs of the family and is keen on its performance in building the right individual. He stressed that relationships, including marriage, should be based on affection and mercy. Marriage is the source of happiness, tranquility and prosperity, and this is only if the couples are in full health and well-being. Marriage that can make a change for the better in the health of society in general and the health of the family in particular, which reflected positively in the sustainability of married life (Al Marzouqi, 2014). 
A premarital medical examination is defined as a set of laboratory and clinical tests that are proposed to any partners before they are associated with a marriage contract to advise them to achieve a happy married life and healthy children and thus a healthy family and a healthy society (Al Qudah, 2003).

Therefore, we cannot ignore the medical examination before marriage as one of the most important preventive health care because it is very important to avoid many diseases, especially genetic and familial, which are prevalent in our Arab societies, and this may be attributed to the increase in the proportion of marriage between relatives and increase the possibility of confluence Genes that cause hereditary disease, many studies have confirmed that the incidence of blood diseases, birth defects, common mono synthetic diseases and disabilities are largely caused by the lack of premarital medical examination, where there is greater chance of occurrence of these diseases when the marriage of relatives, the chances are greater in assuming recessive genetic traits when each parent carries the causative character of the disease, which negatively affects family life and leads to disintegration and disorientation.

The problem of disability is widespread in many Arab countries. Some studies confirm that the number of disabled people in some Arab countries may reach (13\%) of the population. Hence, the idea of resorting to issuing a law requires that those entering the marriage undergo a compulsory medical examination to ensure that the couple, for whatever reasons their children are subjected to malformations, is a law imposed by many Arab countries, including Jordan (Obeidi, 2005).

It is no secret that there are cases of mating between relatives in the Arab society in general by a large percentage that reached $(50 \%)$ in the Gulf community, as a result of this mating between relatives there is a clear increase in genetic diseases, especially transmitted genetic diseases such as genetic blood and birth defects of all kinds and a lot of these diseases may be difficult to treat or need constant and expensive care of the social, psychological and financial aspects that burden the family, so it is essential that specialists try to reduce the number of children who suffer from these diseases and try to reduce the psychological and social effects on families which is the most prevalent diseases, through awareness of the importance of medical examination before marriage (Abdel Jalil, 2016).

Counseling about pre-marital medical examination is carried out through genetic counseling programs, during which the couples who are to marry are given information on the effect of genetic factors on the fetus and the importance of pre-marital testing and analysis. This is to educate parents about the effect of genetic factors, and the difference in the (RH) factor between mother and fetus (Beblawi, 2006).

The family plays an important preventive role by identifying the factors causing the disability through awareness and maintaining the safety and health of children before or after birth, thus preventing the occurrence of disability in their members through the medical examination before marriage and the detection of cases of both spouses before the ceremony Marriage through the services provided by the State institutions for individuals represented by the activation of family health programs and pre-marital medical examination and medical and genetic counseling and awareness campaigns and health education (Khatib \& Hadidi, 2011).

Many people have a fear of premarital examination as a result of their misinterpretation of its reality, it is not intended, as is the case, to exclude or disperse those who agreed to marry when a health problem was discovered, for example, but rather to find a quick solution and advices to avoid the complications that can be happened after marriage, the tests do not stop at the deformities and genetic diseases only, but enter the normal diseases that can be cured with several vaccinations only, the purpose of pre-marital medical tests is to benefit and prevent and not to separate the couples (Beblawi, 2006).

\subsection{Problem of the Study}

Despite the importance of pre-marital medical examinations for the prevention of infectious and genetic diseases, these tests are also new to the culture of community practices, and there are many people resist everything new he is not familiar with it and is not used to it, there are many members of the community are still strongly reject the fact of the premarital medical examination and consider it a defect should not go into it or hint at it, because it carries within it an insult to the other party that cannot be forgotten, and because medical examination before marriage is related to the customs of marriage which are characterized by stability and relative stability, it may be one of the social factors that affect the person's acceptance of the medical examinations (Al Maghrabi, 2009)

The health of the community and its safety from the health and safety of the family and the safety of the individual so many strategies have emerged to prevent genetic disorders and congenital malformations, and the attention to public health and community health and preventive medicine increased at the global and local level and the view of primary health care appeared and became more comprehensive and accessible to all members of 
the community, based on scientifically and socially acceptable methods and techniques.

Studies indicate that the spread of hereditary blood diseases in the third world countries is very large, which in some countries, including Jordan, is a serious health problem and exhaustion of the resources allocated to the health sector. The Jordanian society also has frequent marriages with relatives like other Arab countries, which may lead to high prevalence of Thalassemia. The scientific research in the field of genetics has been very important in identifying many genetic factors responsible for some organic and mental diseases, as well as the discovery of many infectious diseases.

It is possible to reduce the transmission of some diseases between spouses, as well as to reduce the transmission of some mental and organic diseases caused by genetic factors. Despite the importance of pre-marital medical examination for the prevention of genetic diseases, the attitudes of many members of society are still different from this scrutiny and its importance. People usually stand in opposition to any new action they have not known before, especially when it comes to their habits and values.

Therefore, the problem of the current study is to try to identify the attitudes of the students of Amman Arab University towards pre-marital medical examination and its role in reducing the incidence of disability from their point of view, and identify the factors associated with this role by answering the questions of the study.

\subsection{Questions of the Study}

This study attempts to answer the following questions:

1) What are the attitudes of the students of Amman Arab University towards pre-marital medical examination?

2) Do the attitudes of the Arab University of Amman towards pre-marital medical examination different according to gender (male, female) and type of college (scientific, human)?

3) What is the role of pre-marital medical examination from the point of view of the students of Amman Arab University?

4) Does the role of pre-marital medical examination differ from the point of view of the students of Amman Arab University according to gender (male, female) and type of college (scientific, human)?

\subsection{The Importance of the Study}

The importance of the current study is as follows:

\subsubsection{Theoretical Importance}

1) The present study provides theoretical frameworks for the variables of the study, and the results of the study are a qualitative addition in the field of educational and psychological sciences.

2) The importance of the study stems from the fact that it deals with the students of the university, which is considered an educated segment of the Jordanian society; therefore, this segment will represent the future of Jordanian society.

3) The importance of the theoretical study stems from the fact that it contributes in helping researchers, parents, prospective couples, medical professionals and the special education sector in directing them to pay attention to the upbringing and safety of their children in the future.

4) To draw the attention of researchers and those who are interested to conduct more studies that work on exposure to the role of different medical examinations in the prevention of many diseases.

\subsubsection{Practical Importance}

The importance of this study is clear in that it is:

1) The practical importance of the scientific service provided by this study to those responsible for benefiting from the results of the study in the field of special education and specifically the staff and specialists in the field of prevention and early intervention.

2) The present study provides scales to detect the attitudes of students at Amman Arab University toward pre-marital medical examination and its role in reducing disability, this helps researchers to carry out studies that contribute to the enrichment of scientific knowledge in various aspects providing a multidimensional assessment model for the role of premarital medical screening in reducing disability.

\subsection{Objectives of the Study}

The study aims to:

1) Identifying the attitudes of the students of Amman Arab University toward pre-marital medical examination 
2) Identify the role of prenuptial examination in reducing the appearance of disabilities.

3) Determining the extent to which the views of the students of Amman Arab University affect the impact of the medical examination on alleviating disabilities.

4) To identify the effect of the difference in (gender and type of college) on the response of the study sample.

\subsection{Procedural Definitions}

Attitudes: the extent of acceptance or non-acceptance of the idea of a pre-marriage medical examination and is measured by the degree to which students obtain on the scale prepared for this purpose.

Pre-marital medical examination: A set of laboratory and clinical tests that are proposed to any partners before they are associated with the marriage contract to advise them to achieve a happy married life, healthy children and thus a healthy family and a healthy society.

Students of Amman Arab University: These students are enrolled in the bachelor's and master's programs from different levels of study and specialization for the academic year 2017-2018.

Disability: Physical, mental or psychological injury that causes harm to the child's physical or mental development or both, and may affect his / her mental state and the development of his / her education and training.

\subsection{Limitations and Limits of the Study}

The current study was limited to the following:

Human limits: This study was limited to a sample of the students of Amman Arab University and thus can not be generalized; only samples have the same characteristics of the sample of this study.

Time Limits: The first semester of the academic year 2017/2018.

Spatial limits: Amman Arab University.

Objective Limits: The study was limited to the following limits of knowing the role of pre-marital medical examination in reducing the appearance of disability.

\section{Previous Studies}

Several Arabic and foreign studies were conducted on pre-marital medical examinations, especially on young people.

Mohamed, Lamadah, and Hafez (2015) conducted a study in Egypt aimed at assessing the knowledge and attitudes of male and female medical and non-medical students at Minia University towards genetic counseling and prenatal testing and assessing the impact of an educational program on improving the extent of students' knowledge and attitudes towards the importance of premarital medical examination, the data was collected through a questionnaire designed by researchers to collect data from 500 students in four faculties (two medical college and two non-medical colleges) at Minia University, they were given an educational program on the importance of counseling and pre-marital medical examination. The results of the study showed that there is a clear statistical indication regarding improving the overall knowledge of students in the process of counseling and pre-marital medical examination, where the level of knowledge of students towards the process of genetic counseling and premarital examination increased from $32.3 \%$ to $54 \%$ among students of medical colleges, the percentage of students in non-medical colleges increased from $21.0 \%$ to $41.0 \%$, the difference was therefore clear, and the attitudes of the students as a whole towards the pre-marriage genetic counseling process increased from $(54.7 \%)$ to $(66.0 \%)$, at the end of the study, the researchers recommended the need to increase awareness-raising educational programs on the importance of genetic counseling and pre-marital examination in secondary schools to reduce the risk of unhealthy births.

Wang et al. (2013) conducted a study aimed at ascertaining the attitudes of prospective couples to marriage due to pre-marriage voluntary medical examination after the abolition of the mandatory screening in China. This study was conducted between (1/6/2013-31/8/2013) on a sample of a total of (650) couples who plan to marry. They were registered at the Civil Affairs Bureau in Wuhan City, Siuhu City and Zuyang City in Hu Province in central China after collecting the data from the study sample through the questionnaire, as well as their opinion on the most important factors affecting their participation in prenuptial medical examination, were used Analysis of logistic regression in the examination of the factors affecting their participation in prenuptial examination.

The results of the study showed that $34.8 \%$ of the sample of the study conducted a medical examination despite the absence of a legal requirement for this examination. It also revealed that many demographic factors such as age, 
place of residence and profession. As well as awareness, knowledge, and attitudes towards pre-marital screening had a significant impact on participation in the screening program. The study also found that health education and various health activities have a role in increasing knowledge and positive attitudes toward pre-marital screening and thus contribute to increasing the rate of voluntary screening of those who are to marry.

A study was conducted by Al Kindi; Al-Rujaibi, and Al Kendi (2012), aimed at identifying the attitudes of the students of Qaboos University in the Sultanate of Oman towards the pre-marriage screening program. The study was applied to 590 male and female students of unmarried persons whom a questionnaire prepared for this purpose applied on them, it consisted of three parts: the first part included demographic information on the social status of the student, the second part included questions about the extent of the student's knowledge of the prenuptial screening program, while the third part of the questionnaire included the survey of students' attitudes toward conducting a pre-marital screening.

The results of the study showed that the vast majority of the study sample was interested in providing pre-marriage screening program in the Sultanate of Oman, where $(36 \%)$ of the sample expressed their opinion about the possibility of spreading awareness about pre-marriage screening program through schools and colleges, while 35\% saw the possibility of spreading awareness about the pre-marital screening program through various means of communication. The rest of the sample pointed to the possibility of spreading awareness about pre-marital medical examination through families and friends, and health services. The results of the study showed that $(92 \%)$ of the respondents recognized the importance of applying the pre-marital screening program.

Al Maghrabi (2009) conducted a study entitled University youth attitudes towards pre-marital medical examination in Saudi society. The study was applied to a sample of students of King Saud University expected to graduate in the academic year 2007-2008. The researcher used a scale of several studies to detect the attitudes of students towards pre-marital medical examination. The results indicated that females support pre-marital medical examination more than males, and that students in scientific colleges have a positive attitude towards pre-marital medical examination.

Mater and Gharaibeh (2009) conducted a study in Syria aimed at identifying the knowledge and perceptions of Syrian youth about pre-marital medical examination, the study used the descriptive survey method, the study sample consisted of 942 Syrian university students. The researchers used a questionnaire designed to measure the knowledge and attitudes of sample members towards pre-marital medical examination. The results of the study showed that Syrian university students have great knowledge regarding pre-marital medical examination; the results indicate that although there are positive attitudes towards pre-marital medical examination, there are some negative attitudes towards this examination.

Jokhab (2008) conducted a study aims at identifying the differences between the attitudes of girls of marriage age towards pre-marital medical examination, depending on the social situation in terms of whether the girl is coming to marriage or not to marry, in addition to some other demographic variables, the researcher used a scale to measure the trends towards pre-marital medical examination. The sample consisted of (180) girls to marry and 500 girls who were not expected to marry from the students of Imam Muhammad bin Saud University. The results revealed that there were statistically significant differences between the attitudes of girls of marriageable age to pre-marital medical examination according to their social status in terms of whether they are going to marry or not, for the benefit of girls who were not ready to marry. The results also showed the possibility of arranging trends towards the medical examination based on its importance in terms of medical, social, psychological, religious, cultural, and media aspects.

Ahmad (2007) conducted a study aimed to determine the attitudes of university youth towards the importance of pre-marital medical examination and to develop a suggested vision for the role of the individual to support the positive trend and to adjust the negative trend toward the subject of the study, a comparative descriptive study, was applied to a random sample of (230) students from the social service and pharmacology, with (184) students from the Faculty of Social Work, and (46) students from pharmacology college at Helwan University. The following tools were used: an interview form to determine the trend of university youth toward pre-marital medical examination, the most important results were: the trend of youth towards the subject was positive; pre-marital medical examination was linked to youth awareness; but they need to support this attitude, only few of them have negative attitudes towards the subject, and need to develop awareness and thought and information to modify this behavior.

Al Bather (2005) also conducted a study entitled "Trends of Saudi Secondary School Students in Pre-Marital Examination and Counseling in the Eastern Region"; the researcher used a questionnaire to measure the attitudes of the students on a sample of 1216 secondary students who are unmarried. 
The results indicate that there is a relationship between the information of the students about the examination and genetic counseling before marriage and the experience of the incidence of hereditary blood disease and their attitudes in the same field. The more information they have the more positive the trend becomes, where the source of information for the students was mostly from the school and not from the health team. Although there is a positive trend in the sample of the study towards genetic testing and advice, it was found that there is a weakness in the type of information about genetic blood diseases, examination and genetic counseling before marriage, which has an impact on behavior in the future.

Obeidi (2005) conducted a study aimed at identifying the attitudes of King Saud University students towards the dimensions of the medical examination for the purpose of marriage, which is the importance of conducting the medical examination for the purpose of marriage. The data were collected to achieve the objectives of this study and answer their questions using a form applied on a sample of 3000 students representing $6.79 \%$ of the study population, males represent $62 \%$ and females represent $38 \%$ of the total sample selected through cluster random sampling.

The results of this study indicate that there is a positive trend among the respondents towards the different dimensions of the premarital medical examination variable, where one out of every twenty respondents who believe that the premarital medical examination is useless, there is one out of 25 refuse conducting this examination if the other party stipulated that, and about four out of every 25 respondents who prefer to marry insisting on marrying their relatives even if this involves health risks, there is one out of every 10 insists on marrying who they want, even if the tests reveal that there are health barriers, and one out of every twenty respondents their intention is not to conduct a medical examination, and more than $14 \%$ of the respondents did not support the issuance of a system requiring medical examination for the purpose of marriage.

\section{Method and Procedures}

\section{Study Methodology:}

This study used the descriptive method for its suitability for the purposes of this study.

\subsection{Population of the Study and Its Sample}

The study population consists of all undergraduate and master's students at Amman Arab University from the different faculties and academic years for the year (2017-2018) who were consisted of (1600) male and female students, (200) students were selected in a simple random way.

\subsection{Study Tool}

The researchers used a questionnaire; the study tool was in its final form of 24 items, and benefit from the study of Wang et al. (2013) and the study of Al Maghrabi (2009).

\subsubsection{Validity of the Tool}

In order to verify the validity of the study tool, it was presented to a group of specialized arbitrators. The amendments were made in the light of the observations they made.

\subsubsection{Reliability of the Study Tool}

The study tool was applied to a pilot sample outside the study sample. Two weeks later, the application was re-applied. The correlation coefficient between the two application periods was 0.86 .

\subsection{Data Analysis}

The data were analyzed by the statistical pouch program (Statistical Package for Social Science-SPSS) basic descriptive statistics in the analysis of the study results where frequency, percentage, arithmetic mean, standard deviation, and Kai square ( $\mathrm{X}^{2}$-test) were used, and the analysis of variance (F-test) in order to determine the significance of differences between the response of the members of the study sample according to the variables of the study and the relationship between the information and the response of the members of the study sample according to the study variables, the level of significance is significant if it is less than $(\mathrm{P}<0.05)$.

\section{Results of the Study}

\subsection{Results Related to the First Question}

What are the attitudes of the students of Amman Arab University towards pre-marital medical examination, and what is their role?

In order to answer the first question, the arithmetic mean was found for both trends and the role of pre-marital medical examination. The following tables show this. 
First: Attitudes

Table 1. Means, standard deviations, ranks and degrees of the attitudes of the students of Amman Arab University towards pre-marital medical examination

\begin{tabular}{|c|c|c|c|c|c|}
\hline Range & Items & Mean & $\begin{array}{l}\text { Standard } \\
\text { deviation }\end{array}$ & Rank & $\begin{array}{l}\text { Degree of } \\
\text { practice }\end{array}$ \\
\hline 11 & I see that pre-marital medical examination leads to the well-being of the family & 4.53 & 0.69 & 1 & High \\
\hline 9 & My parents encourage me to take a premarital examination & 4.49 & 0.66 & 2 & High \\
\hline 10 & Those who plan to marry must do the examination & 4.48 & 0.63 & 3 & High \\
\hline 12 & I am ashamed to go for a pre-marital examination & 4.43 & 0.75 & 5 & High \\
\hline 15 & $\begin{array}{l}\text { I am afraid that I cannot associate with someone I love because of my pre-marital } \\
\text { examination }\end{array}$ & 4.40 & 0.74 & 6 & High \\
\hline 20 & $\begin{array}{l}\text { It is essential that the Pre-Marriage Medical Examination Act be fully } \\
\text { implemented }\end{array}$ & 4.38 & 0.81 & 7 & High \\
\hline 3 & Doctors' opinion on the need for prenuptial examination is exaggerated & 4.32 & 0.82 & 8 & High \\
\hline 14 & $\begin{array}{l}\text { I am not convinced of the importance of prenuptial examination as a measure to } \\
\text { reduce the incidence of disability }\end{array}$ & 4.32 & 0.85 & 8 & High \\
\hline 8 & $\begin{array}{l}\text { Marriage with non-relatives may make the results of premarital medical } \\
\text { examination more positive }\end{array}$ & 4.31 & 0.80 & 10 & High \\
\hline 17 & Premarital examination is a social moral law to avoid births of disability & 4.30 & 0.85 & 11 & High \\
\hline 19 & $\begin{array}{l}\text { Pre-marital medical examination reflects the development and progress of } \\
\text { communities }\end{array}$ & 4.28 & 0.74 & 12 & High \\
\hline 7 & $\begin{array}{l}\text { I think premarital examination is not a defect, it is a preventive process to reduce } \\
\text { the incidence of disability }\end{array}$ & 4.27 & 0.84 & 13 & High \\
\hline 13 & $\begin{array}{l}\text { Pre-marital examination is a quick and clear solution to avoid family } \\
\text { complications that can occur after marriage as a result of the birth of a disability }\end{array}$ & 4.26 & 0.87 & 14 & High \\
\hline 5 & $\begin{array}{l}\text { The results of a premarital examination may be a reason for the success and } \\
\text { strengthening of the marital relationship }\end{array}$ & 4.26 & 0.90 & 14 & High \\
\hline 4 & $\begin{array}{l}\text { I think it is necessary to raise awareness of the importance of medical } \\
\text { examination before marriage }\end{array}$ & 4.25 & 0.83 & 15 & High \\
\hline 16 & I see that pre-marital examination does not fit the habits of society & 3.33 & 0.73 & 4 & Medium \\
\hline \multicolumn{2}{|c|}{ Total score } & 4.31 & 0.59 & & High \\
\hline
\end{tabular}

It is noted from Table 1 that the arithmetic mean of the total score of youth attitudes was high with the mean (4.31) and the standard deviation (0.59). The items of the scale were high, except for one item that came in the middle, and in the first rank came item (11) which states "I see that pre-marital medical examination leads to the well-being of the family." In the last rank came item (16) which states: "I believe that pre-marital examination does not fit the customs of society.

Second: The role of medical examination from the perspective of young people 
Table 2. Means, standard deviations, ranks and degrees of students' role towards pre-marriage examination from their point of view

\begin{tabular}{|c|c|c|c|c|c|}
\hline Range & Items & Mean & $\begin{array}{l}\text { Standard } \\
\text { deviation }\end{array}$ & Rank & $\begin{array}{c}\text { Degree of } \\
\text { practice }\end{array}$ \\
\hline 21 & $\begin{array}{l}\text { Compliance with the results of pre-marital medical examination will positively } \\
\text { reflect on the health of family members in the future }\end{array}$ & 4.65 & 0.62 & 1 & High \\
\hline 22 & Pre-marital examination may lead to solutions to future problems & 4.60 & 0.59 & 2 & High \\
\hline 15 & $\begin{array}{l}\text { Premarital medical examination is not necessary because there are many couples } \\
\text { who do not have a previous disability }\end{array}$ & 4.55 & 0.61 & 3 & High \\
\hline 25 & There is an urgent need for a premarital medical examination & 4.54 & 0.65 & 4 & High \\
\hline 16 & $\begin{array}{l}\text { Pre-marital medical examination contributes to the prevention of genetic } \\
\text { diseases }\end{array}$ & 4.53 & 0.69 & 5 & High \\
\hline 14 & $\begin{array}{l}\text { A premarital medical examination will pay attention to the future safety of my } \\
\text { family members }\end{array}$ & 4.45 & 0.71 & 6 & High \\
\hline 23 & $\begin{array}{l}\text { Pre-marriage medical examination procedures are preferred to be applied } \\
\text { mandatory }\end{array}$ & 4.43 & 0.78 & 7 & High \\
\hline 17 & $\begin{array}{l}\text { The application of premarital medical examination has a benefit for the couple } \\
\text { and their children in the future }\end{array}$ & 4.33 & 0.76 & 8 & High \\
\hline 24 & $\begin{array}{l}\text { Not conductinga premarital examination leads to fears of spreading of chronic } \\
\text { disability }\end{array}$ & 4.33 & 0.78 & 8 & High \\
\hline 13 & $\begin{array}{l}\text { Not conducting pre-marital medical examination may lead to therapeutic } \\
\text { burdens for children in future }\end{array}$ & 4.30 & 0.78 & 9 & High \\
\hline 18 & $\begin{array}{l}\text { The implications of not having a premarital medical examination are } \\
\text { overestimated }\end{array}$ & 4.25 & 0.75 & 10 & High \\
\hline 3 & $\begin{array}{l}\text { Conducting medical examination may prevent the family many economic } \\
\text { problems resulting from the effects of disability }\end{array}$ & 4.23 & 0.85 & 11 & High \\
\hline 12 & $\begin{array}{l}\text { Conducting medical examination may prevent the family many social and } \\
\text { psychological problems resulting from the effects of disability }\end{array}$ & 4.23 & 0.86 & 11 & High \\
\hline 20 & $\begin{array}{l}\text { Pre-marital medical examination protects the community from the spread of } \\
\text { diseases and reducing it }\end{array}$ & 4.18 & 0.74 & 13 & High \\
\hline 7 & $\begin{array}{l}\text { Pre-marital medical examination helps to ensure the safety of the fetus in the } \\
\text { womb from diseases, malformations and disabilities }\end{array}$ & 4.15 & 0.89 & 14 & High \\
\hline 9 & $\begin{array}{l}\text { A premarital medical examination checks the presence of chronic diseases that } \\
\text { affect life after marriage }\end{array}$ & 4.13 & 0.90 & 15 & High \\
\hline 19 & $\begin{array}{l}\text { Compliance with the results of pre-marital medical examination will positively } \\
\text { reflect on the health of family members in the future }\end{array}$ & 4.11 & 0.82 & 16 & High \\
\hline 5 & Pre-marital examination may lead to solutions to future problems & 4.10 & 0.83 & 17 & High \\
\hline 10 & $\begin{array}{l}\text { Premarital medical examination is unnecessary because many couples do not } \\
\text { have a previous disability }\end{array}$ & 4.07 & 0.88 & 18 & High \\
\hline 2 & $\begin{array}{l}\text { Premarital medical examination before marriage must be made a condition to } \\
\text { complete the marriage }\end{array}$ & 4.06 & 0.89 & 19 & High \\
\hline 11 & $\begin{array}{l}\text { Pre-marital medical examination contributes to the prevention of genetic } \\
\text { diseases }\end{array}$ & 4.04 & 0.91 & 20 & High \\
\hline 1 & $\begin{array}{l}\text { A premarital medical examination will pay attention to the future safety of my } \\
\text { family members }\end{array}$ & 4.03 & 0.84 & 21 & High \\
\hline \multirow[t]{2}{*}{6} & $\begin{array}{l}\text { I think it is not necessary to apply medical examination procedures before } \\
\text { marriage }\end{array}$ & 4.02 & 0.92 & 21 & High \\
\hline & Total score & 4.22 & 0.57 & & \\
\hline
\end{tabular}

It is noted from Table 2 that the mean of the total score of the role of the medical examination from the point of view of young people came to a high level with an arithmetic mean (4.22), a standard deviation (0.57), the items of the scale were high, and the first rank was item (21) which states "The adherence to the results of medical examination before marriage is reflected positively on the health of family members in the future," and in the last rank came item (6), which states, "I see it is not necessary to apply the procedures of medical examination before marriage, this finding can be explained by the students' awareness of the importance and role of pre-marital 
medical examination in alleviating diseases that can be transmitted to children later. This finding was agreed relatively with the study of Al-Abeed (2005), which showed a positive attitude by respondents towards the different dimensions of medical examination for marriage, it also agreed with the findings of the study of (Al Kindi, Al Rujaibi, \& Al Kendi, 2012) which indicated that the vast majority of the study sample are interested in pre-nuptial examination in the Sultanate of Oman.

\subsection{Results Related to the Second Question}

Do the attitudes of the students of Amman Arab University different towards pre-marital medical examinations differ depending on the gender of the student and the college type?

To answer this question, the binary variance analysis was extracted and Table 3 shows this.

Table 3. Results of the variance analysis to examine the significance of the differences between the arithmetic mean of the students of Amman Arab University towards the medical examination according to the gender of the student and the type of college

\begin{tabular}{lccccc}
\hline Source & Type III Sum of Squares & df & Mean Square & F & Sig. \\
\hline Gender & 0.342 & 2 & 0.171 & 0.590 & 0.555 \\
College & 0.122 & 1 & 0.122 & 0.421 & 0.517 \\
Gender * College & 0.046 & 1 & 0.046 & 0.159 & 0.691 \\
Error & 56.415 & 195 & 0.289 & & \\
Total & 3738.165 & 200 & & & \\
Corrected Total & 57.055 & 199 & & & \\
\hline
\end{tabular}

Table 3 shows that there are no differences due to the gender of the student or the type of college. The significance value of "F" is greater than $(0.05)$ for each case. This result can be explained by the fact that male and female students have the same awareness of the importance and role of medical examination, this finding was consistent with the study of Al Kindi, Al Rujaibi, and Al Kendi (2012), which indicated that the vast majority of the study sample is interested in pre-marital examination in the Sultanate of Oman, and inconsistent with the study of Al-Maghrabi (2009) which indicated that females support pre-marital medical examination more than males, and this result was agreed with the study of Al Bather (2005), which indicated that there was a positive trend for the sample of the study towards pre-marital medical examination, and agreed with the result of the study of Wang et al. (2013). Health education and various health activities have a role in increasing knowledge and positive attitudes towards pre-marital examination and thus contribute to an increase in the voluntary examination rate for those who are new to marriage.

\subsection{Results Related to the Third Question}

Does the role of the students of Amman Arab University differ from the pre-marital medical examination according to the gender of the student and the type of college?

To answer this question, the binary variance analysis was extracted and Table 4 shows the result.

Table 4. Results of the variance analysis to examine the significance of the differences between the arithmetical averages of the trends of the students of the Arab University of Amman towards a role for the medical examination according to the gender of the student and the type of college

\begin{tabular}{lccccc}
\hline Source & Type III Sum of Squares & df & Mean Square & F & Sig. \\
\hline Gender & 0.434 & 2 & 0.217 & 0.592 & 0.554 \\
College & 1.259 & 1 & 1.259 & 3.429 & 0.066 \\
Gender * College & 0.373 & 1 & 0.373 & 1.015 & 0.315 \\
Error & 71.577 & 195 & 0.367 & & \\
Total & 3713.630 & 200 & & & \\
Corrected Total & 73.577 & 199 & & & \\
\hline
\end{tabular}

It is noted from Table 4 that there are no differences due to the gender of the student or the type of college. The significance value of " $F$ " is greater than $(0.05)$ for each case. This result may be attributed to the students' awareness of the importance and role of this test in reducing disease and establishing a successful family, and 
this result was agreed with the study of Al Kindi, Al Rujaibi, and Al Kendi (2012) which indicated that the vast majority of the study sample are interested in pre-nuptial examination in the Sultanate of Oman. The results differed with the study of Al Maghrabi (2009), which indicated that females support pre-marital medical examination more than males. This result was also agreed with the study of Al Bather (2005), which indicated a positive trend for the sample of the study sample towards pre-marital medical examination.

\section{References}

Abdul Jalil, M. (2016). Knowledge and attitudes of the family towards the marriage of relatives and medical examination before the marriage. Alexandria Journal of Scientific Exchange, 4(37).

Al Bather, J. (2005). Attitudes of Saudi High School Students to Pre-Marital Examination and Counseling in the Eastern Region (Unpublished master thesis), King Saud University.

Al Jaber, A. (2006). Medical examination before marriage. Journal of College of Sharia and Islamic Studies. Scientific Magazine, Qatar University.

Al Kindi, R., Al Rujaibi, S., \& Al Kendi, M. (2012). Knowledge and Attitude of University Students towards Premarital Screening Program. Oman Medical Journal, 27(4), 291-296. https://doi.org/10.5001/omj.2012.72

Al Maghrabi, S. (2009). University Youth Attitudes towards Pre-Marital Medical Examination in Saudi Society (Unpublished doctoral thesis). King Abdulaziz University.

Al Marzouqi, H. (2014). Medical examination before marriage in Sharia and UAE law according to the rules of Sharia. Journal of Shari'a and Law, 59.

Al Qudah, A. (2003). Medical examination before marriage, necessity or luxury. Amman: Maafat al-Afaf charity.

Beblawi, E. (2006). Awareness of Disability Society (2nd ed.). Dar Al-Zahraa Publishing and Distribution: Riyadh.

Gharaibeh, H., \& Mater, F. (2009). Young Syrian adults' knowledge, perceptions and attitudes to premarital testing. International Nursing Review, 56(4), 450-455. https://doi.org/10.1111/j.1466-7657.2009.00736.x

Hanan, A. (2007). University youth orientation towards the importance of pre-marital medical examination and a proposed proposal to serve the individual to cope with it. Journal of Studies in Social Work and Human Sciences, 23(1).

Jokhab, F. (2008). The trend towards pre-marital medical examination in a sample of Saudi girls (Unpublished master thesis). Imam Muhammad bin Saud University.

Khatib, \& Hadidi. (2011). Early Intervention (Special Education in Early Childhood) (5th ed.). Dar Al-Fikr: Amman.

Mohamed, H., Lamadah, S., \& Hafez, A. (2015) Improving Knowledge and Attitude of Medical and Non-Medical Students at El Minia University Regarding Premarital Screening and Counseling. American Journal of Nursing Science, 4(5), 270-279. https://doi.org/10.11648/j.ajns.20150405.14

Obeidi, I. (2005). University Youth Attitudes toward Medical Examination for the Purpose of Marriage. Riyadh: King Khalid Charitable Foundation.

Wang, P., Wang, X., Fang, M., \& Vander, T. (2013). Factors influencing the decision to participate in medical premarital examinations in Hubei Province, Mid-China. BMC Public Health, 13, 217. https://doi.org/10.1186/1471-2458-13-217

\section{Copyrights}

Copyright for this article is retained by the author(s), with first publication rights granted to the journal.

This is an open-access article distributed under the terms and conditions of the Creative Commons Attribution license (http://creativecommons.org/licenses/by/4.0/). 